\title{
External Hard Particle Size Effect on Changes in Frictional Performance and Grit Embedment during Drag and Stop Mode Braking
}

\author{
M. K. Abdul Hamida*, A. R. Abu Bakara, G. W. Stachowiak \\ ${ }^{a}$ Faculty of Mechanical Engineering, Universiti Teknologi Malaysia, 81310 UTM Johor Bahru, Johor, Malaysia \\ ${ }^{b}$ Tribology Laboratory, School of Mechanical and Chemical Engineering, University of Western Australia, Crawley 6009, Western Australia \\ *Corresponding author: kameil@fkm.utm.my
}

\section{Article history}

Received :1 January 2014

Received in revised form :

10 January 2014

Accepted :20 January 2014

Graphical abstract

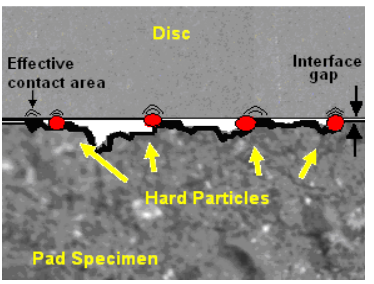

\begin{abstract}
The effects of silica sand of 50-180 $\mu \mathrm{m}, 180-355 \mu \mathrm{m}$ and 355-500 $\mu \mathrm{m}$ on friction performance and grit embedment at brake disc and pad interface was investigated. Results showed that present of external hard particles caused higher friction coefficient due to higher number of smaller particles involved in mixing and changing the effective contact, while good friction stability was attributed to smaller grit particles and compacted wear debris. Grit embedment was greatly dependent on presence of compacted wear debris as most grits were embedded into compacted wear debris with embedment of $0.8 \%$ was observed for $50-180$ $\mu \mathrm{m}, 2 \%$ for $180-355 \mu \mathrm{m}$ and $3 \%$ for $355-500 \mu \mathrm{m}$.
\end{abstract}

Keywords: External hard particle; friction coefficients; particle size; grit embedment

\begin{abstract}
Abstrak
Kesan pasir silica bersaiz 50-180 $\mu \mathrm{m}, 180-355 \mu \mathrm{m}$ dan 355-500 $\mu \mathrm{m}$ ke atas prestasi geseran dan keupayaan grit untuk terbenam pada permukaan cakera brek dan pelapik brek telah di kaji. Hasil kajian menunjukkan kehadiran partikel dari luar menyebabkan peningkatan pekali geseran kerana bilangan partikel bersaiz kecil yang tinggi dalam proses percampuran dan perubahan pada kawasan sentuhan efektif. Sementara itu, kestabilan geseran yang baik adalah dikaitkan dengan partikel kecil dan bahan hakisan yang terkompak. Keupayaan grit untuk terbenam bergantung kepada kehadiran bahan hakisan terkompak kerana kebanyakan grit yang terbenam adalah pada bahagian itu dengan peratusan kawasan terbenam $0.8 \%$ oleh partikel bersaiz $50-180 \mu \mathrm{m}, 2 \%$ untuk $180-355 \mu \mathrm{m}$ dan $3 \%$ untuk $355-500 \mu \mathrm{m}$.
\end{abstract}

Kata kunci: Partikel luaran, pekali geseran, saiz partikel, grit terbenam

(C) 2014 Penerbit UTM Press. All rights reserved.

\subsection{INTRODUCTION}

The friction behavior during braking is not a fully understood problem. This is due to the nature of the brake contact surfaces which is covered and hidden between the pad and the disc during the braking operation. The requirement for the brake coefficient of friction $(\mathrm{CoF})$ is that it should be relatively high and most importantly to be stable, i.e. it should remain stable irrespective of temperature, humidity, age of the pads, degree of wear and corrosion, the presence of dirt and water spray from the road [1] Thus, brake frictional materials are designed to provide stable frictional performance over a wide range of vehicle operating conditions and also to exhibit acceptable durability. Despite the fact that brakes operate under a variety of environmental conditions, many laboratory brake material tests are conducted under dry conditions and only few studies included the dusty or wet braking conditions. The studies of braking under different environments, e.g. the presence of hard particles, are limited in the tribological literature.
The operation of automotive disc brake can be linked to the presence of hard particle derived from the environment [2]. The open design and position of the disc brake close to the road can influence the tribological characteristics of the friction interface due to operating factors. Factors such as humidity and the presence of hard particles in the air can influence the tribological processes and indirectly affect the braking effectiveness. These difficult to control factors, i.e. hard particles and water, are often present and may represent potentially serious tribological problems during braking operation.

In automotive braking, the abrasion at the friction interface is generally caused by the abrasive and hard particles that are included in the composition of the brake pad. These particles are used to control the level of friction force and to remove friction films forming at the sliding interface $[3,4]$. When the brake is applied, the contact between cast iron disc and soft polymer matrix of brake pad produce wear particles. The wear particles move homogeneously through the contact zone until the abrasive particle adheres to the disc surface and get into the contact zone 
[5]. However, dirt and particle from environment also may contribute to the abrasion process at the brake interface where both modes of abrasive wear, i.e. two and three body, can be present. Few of the external hard particles tend to embed into the pad material while some particles together with other contaminants may form a lubricating film but eventually they are expelled from the contact. Therefore, the modes of abrasion often change from two body to three body mode or vice versa during braking operation [6].

During braking, the effect of two-body abrasion tends to be a dominating mechanism while the effect of three-body abrasion is rather small. According to Axen et al. [7] the prerequisite for the two to three body abrasion transition to take place is that the hard particles are sufficiently strong to resist the shearing forces. If the hard particles are crushed then no wear by micro-cutting can take place. Therefore, the abrasion modes and transition between the two and three abrasion modes are important in determining the friction and wear performance of the braking system and they depend on the factors such as particle size, shape volume percent, lubricity and particle-matrix bonding strength [8-11]. Also, the transfer film formed will mediate the interaction between the mating surfaces and change the tribological characteristics at the sliding interface significantly [12]. The transfer film is usually assumed to have compositional mix of both friction materials from the tribological couple and it can also consists of the tribooxidation products [13]. Products such as iron oxides, barium sulphate, copper oxide, copper sulphide, and carbonaceous products were identified after braking $[14,15]$. The transfer films are highly dependent on the braking conditions and the composition of the brake material [16]. The transfer film or third body layers that develop can differ in composition from both mating parts of the tribological couple.

In this work the effect of hard particles from environment, i.e. the silica sand, on the frictional characteristics of braking system and particle embedment was studied. Three different size ranges of silica sand, i.e. between $50-180 \mu \mathrm{m}, 180-355 \mu \mathrm{m}$ and 355-500 $\mu \mathrm{m}$, were used. The experiments were carried out on vertically oriented brake test rig at different sliding speeds and applied contact pressures in order to compare the changes in friction coefficient, the fluctuation of frictional force and to evaluate the particle embedment. Analysis of the fluctuation amplitude of friction coefficient was carried out to find the relationship between particle embedment, sliding speed and applied load.

\subsection{EXPERIMENTAL METHODS}

\subsection{Test Rig}

Special test rig was developed for the purpose of this study, i.e. to conduct the drag and stop mode sliding friction tests under controlled braking conditions. A schematic diagram and the picture of the test rig are shown in Figure 1. The test rig consists of a 1 h.p., three-phase, variable speed induction motor (from Baldor) driving a grey cast iron disc mounted vertically on the shaft. Delta Electronics high performance VF-D series AC motor drive is used to control the speed of the induction motor. The brake pad is attached to a solid cylinder steel and applied to the rotating disc at the 3 o'clock position. A grit particle feeder tube is attached to the hopper to direct the hard particles to the gap between the brake pad and the disc. A manually controlled valve is used to regulate the amount of hard particles delivered to the contact. The brake disc specimen is shielded by a transparent cover to avoid splashing of the grit particles during the experiments.

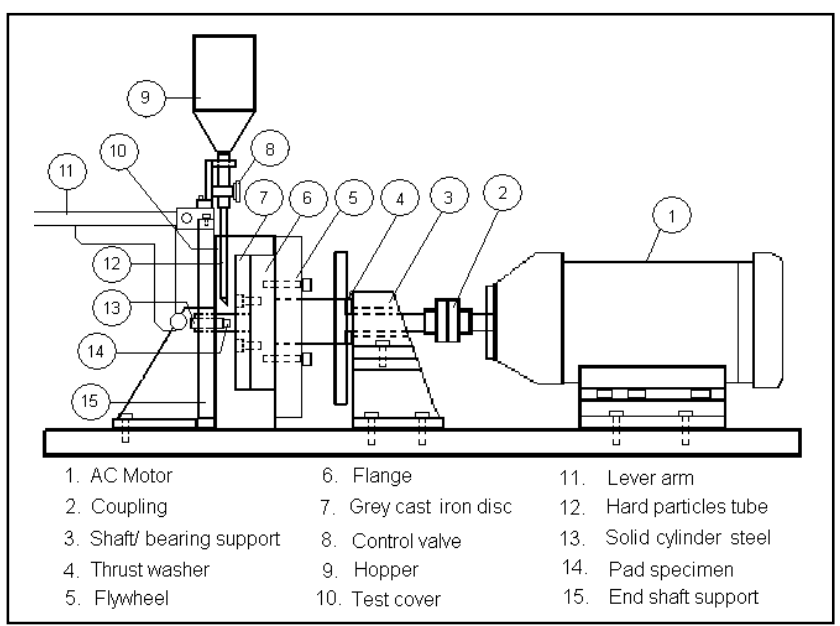

Figure 1 Schematic diagram of the brake test rig

\subsection{Specimen Materials and Testing Procedures}

The contact geometry used during experiments was a flat pad on a flat rotating disc. The pad was a square-faced specimen $\left(12.7 \times 12.7 \mathrm{~mm}^{2}\right)$ cut out from a commercial car disc brake pad. Total thickness of the specimen including the backing plate is approximately $9 \mathrm{~mm}$. The brake disc diameter is $160 \mathrm{~mm}$ and is $10 \mathrm{~mm}$ thick. The disc is machined from a grey cast iron plate and is non-ventilated type. The radial distance from the center of the pad specimen to the center of the turning disc was $63.65 \mathrm{~mm}$. The surface roughness of the discs $\left(R_{\mathrm{a}}\right)$, was measured with a Talysurf profilometer. The microstructure of a typical cross-section of the pad material was analyzed using optical microscope. The microstructure of the pad material being the mixture of shiny metallic constituents of steel fiber, barium sulphate and nonmetallic particles of silicon oxide within a polymeric binder of phenolic resin as shown in Figure 2 was identified using optical microscopy and EDS. The grey cast iron disc material contains of graphite flakes suggesting a typical cast dendritic microstructure [17].

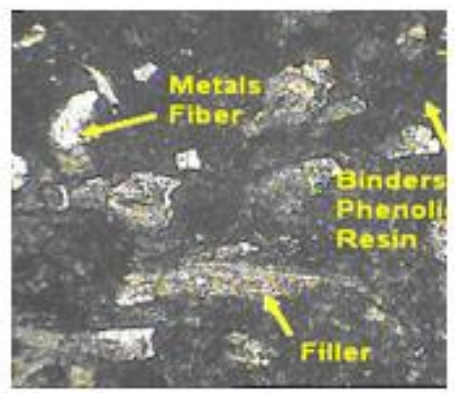

Figure 2 Random distribution of metal fibers (shinny), fillers (long shapes) and binders (dark area) of a brake pad at 20x magnification

\subsection{Specimen Materials and Testing Procedures}

Grit particles were supplied to the gap through the small feeder tube at the rate of $2.5 \mathrm{gm} / \mathrm{s}$. The gap between the disc and pad specimen was about $1.0 \mathrm{~mm}$. The running-in of the pad specimen was carried out for five minutes using a constant braking pressure 
of $0.6 \mathrm{MPa}$ for surface adjustment of the contact areas. Sieving for different particle size range was carried out using the Endecotts sieves. Silica sand particles were sieved for 15 minutes into three size ranges of $50-180 \mu \mathrm{m}, 180-355 \mu \mathrm{m}$ and $355-500 \mu \mathrm{m}$. A series of short duration drag mode tests at four different sliding speeds of $4 \mathrm{~m} / \mathrm{s}, 8 \mathrm{~m} / \mathrm{s}, 10 \mathrm{~m} / \mathrm{s}$ and $12 \mathrm{~m} / \mathrm{s}$ at constant pressure of 0.6 $\mathrm{MPa}$ and $0.8 \mathrm{MPa}$ were used to evaluate the hard particles size effects on the change of friction coefficient and particle embedment. Change of CoF values is related to the consistency of friction force at sliding interface and is also known as the friction stability. The term friction stability describes the consistency of friction force at different speeds and applied pressure. Therefore it can be used as brake stability indicator since to have good friction stability means to maintain the same level of friction force at different braking condition. Stop mode test was also carried out at constant pressure of 1.0 MPa. The detailed test procedures are given in Table 1. Evaluation of the grit particle embedment was conducted using SEM and optical microscopy to study correlations with different sliding speeds, applied pressures and particle grit sizes.

Table 1 Testing procedures

\begin{tabular}{ccc}
\hline Parameter & $\begin{array}{c}\text { Short drag test } \\
\text { (with and without } \\
\text { grit particles) }\end{array}$ & $\begin{array}{c}\text { Hard braking } \\
\text { (only with grit } \\
\text { particles) }\end{array}$ \\
\hline Pressure $(\mathrm{MPa})$ & $0.6,0.8$ & 1 \\
Speed $(\mathrm{m} / \mathrm{s})$ & $4,8,10,12$ & $3,8,10,12$ \\
Duration $(\mathrm{s})$ & $3 \times 10 \mathrm{~s} *$ & $3 \mathrm{x}^{*}$ \\
\hline & & \\
$* 10$ seconds $[\mathrm{s}]$ braking is applied for three times. \\
$* *$ braking is applied until the disc stops for three times
\end{tabular}

Test data was collected using the Agilent U2300A Series USB multifunction data acquisition system. Parameters such as sliding speed, pad normal force, friction force, and instantaneous friction coefficient were recorded during each test. A data sampling rate of $120 \mathrm{~Hz}$ was used for all the experiments. Test data was then analyzed and displayed using MATLAB.

\subsection{RESULTS AND DISCUSSION}

\subsection{Effect of Particle Size on Friction Coefficients (CoF)}

During drag mode experiments, the effects of grit particle on the friction coefficient $(\mathrm{CoF})$ were analyzed and compared to the case where no grit particle was present. Silica sand at a rate of 2.5 gram/s was delivered to the brake gap and short duration braking of 10 second [s] was applied three times for every test to measure the changes of $\mathrm{CoF}$ occurring. Results obtained showed that the presence of grit particles from environment can influence the friction response significantly. Once the particles enter the gap, the value and amplitude of friction coefficient tend to change with the speed and load applied. The changes of $\mathrm{CoF}$ measured at four sliding speeds during the drag test at constant pressure of $0.6 \mathrm{MPa}$ and $0.8 \mathrm{MPa}$ without and with the grit particles of 50-180 $\mu \mathrm{m}$ are shown in Figure 3(a) and (b).

The grit particles tend to lower the CoF for both pressures, but specifically at the lower sliding speed. At $0.6 \mathrm{MPa}$, average $\mathrm{CoF}$ values were reduced to about 0.35 from 0.47 for low sliding speed in the presence of the grit particles and for $8 \mathrm{~m} / \mathrm{s}$ the CoF was reduced to the minimum average of 0.43 from 0.49 . However, at speeds of $10 \mathrm{~m} / \mathrm{s}$ and $12 \mathrm{~m} / \mathrm{s}$ there was an increase in the $\mathrm{CoF}$ values during the tests with grit particles. At $0.8 \mathrm{MPa}$, the $\mathrm{CoF}$ values were reduced for all the speeds, but this time the change was smaller. This appeared to occur partly because of the higher load applied to the braking interface and partly because of changes in the effective contact of the pad and disc, caused by the grit particles entering the sliding contact.

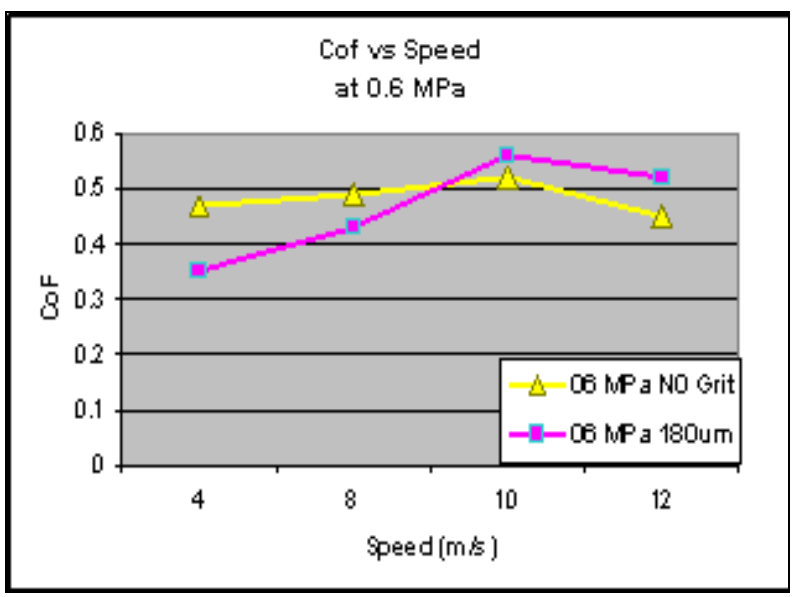

(a)

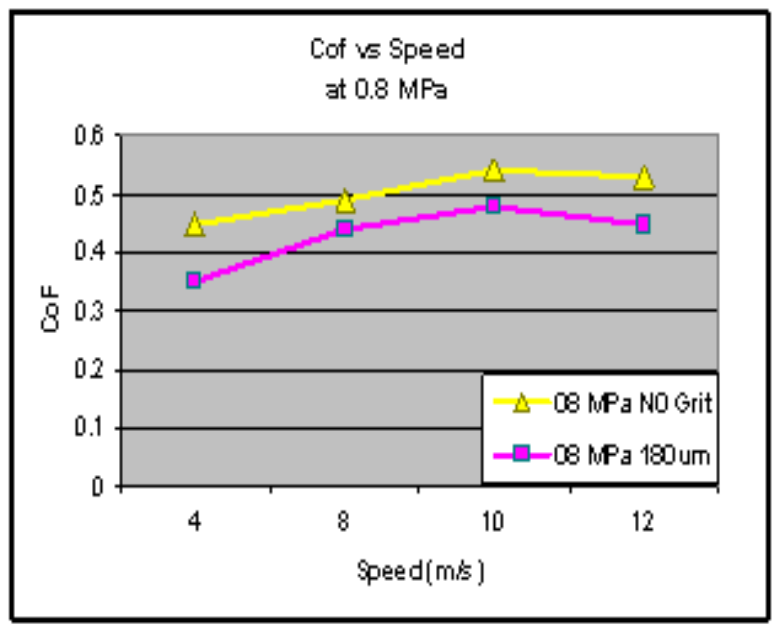

(b)

Figure $3 \mathrm{CoF}$ changes with disc sliding speed measured at constant pressure of (a) $0.6 \mathrm{MPa}$ and (b) $0.8 \mathrm{MPa}$ for the tests without and with the grit particles

The changes of $\mathrm{CoF}$ for different grit particle sizes measured at $4 \mathrm{~m} / \mathrm{s}$ (low) and $8 \mathrm{~m} / \mathrm{s}$ (medium) during the drag test at constant pressure of $0.6 \mathrm{MPa}$ are shown in Figure 4 and 5. It can be seen from Figure 4 that $\mathrm{CoF}$ values were reduced to about 0.31-0.35 from $0.43-0.49$ for grit size of $355-500 \mu \mathrm{m}$. For grit size in the range between 180-355 $\mu \mathrm{m}$ the $\mathrm{CoF}$ was in the range of $0.31-0.38$ and $0.41-0.47$ for grit size 50-180 $\mu \mathrm{m}$. In Figure 5, presence of grit particle at medium sliding speed has similar effect but with smaller reduction of $\mathrm{CoF}$. The $\mathrm{CoF}$ was reduced to a minimum average of $0.42-0.48$ from $0.50-0.52$ with grit size of $355-500 \mu \mathrm{m}$, to $0.41-0.47$ for the grit size of $180-355 \mu \mathrm{m}$ and to $0.48-0.55$ for grit size $50-180 \mu \mathrm{m}$. 


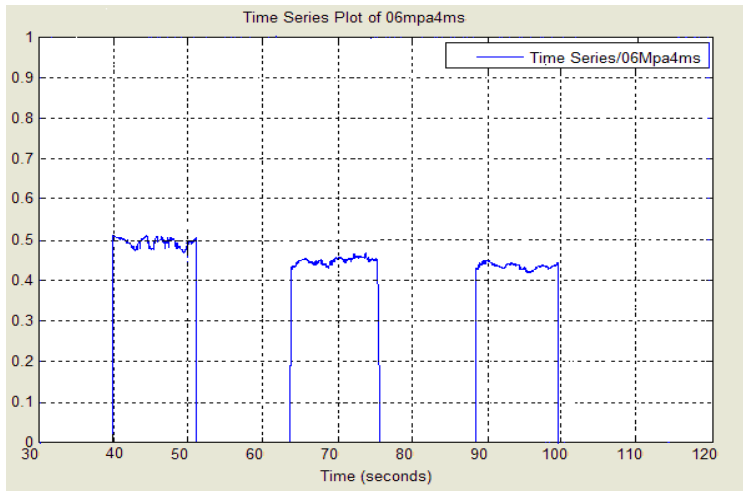

(a)

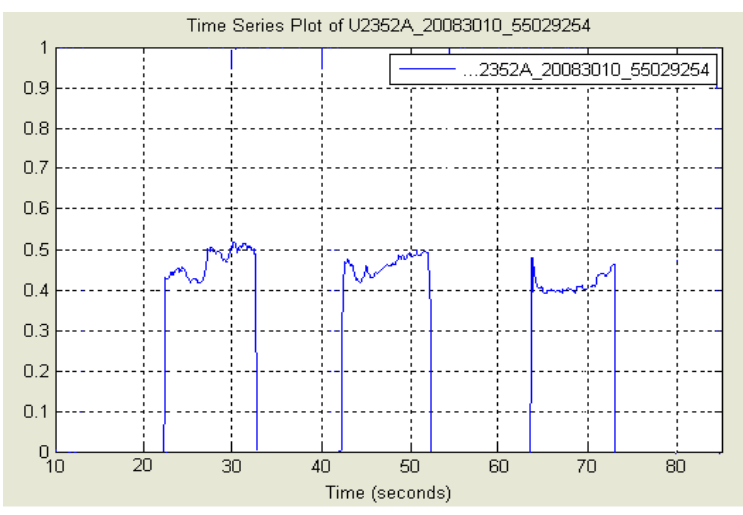

(b)

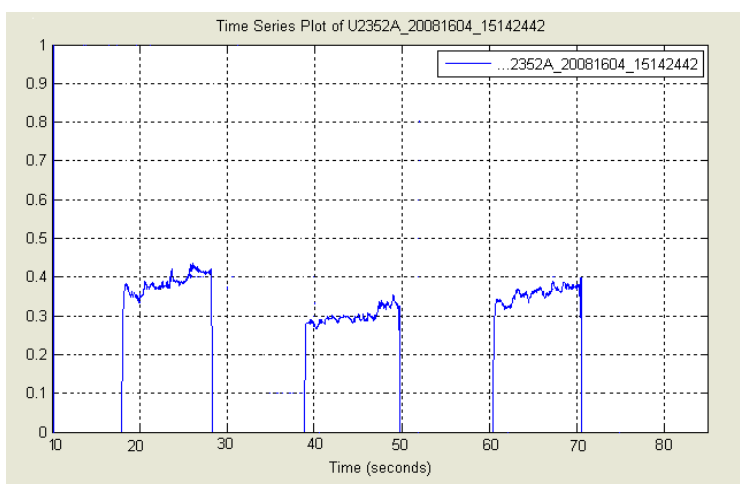

(c)

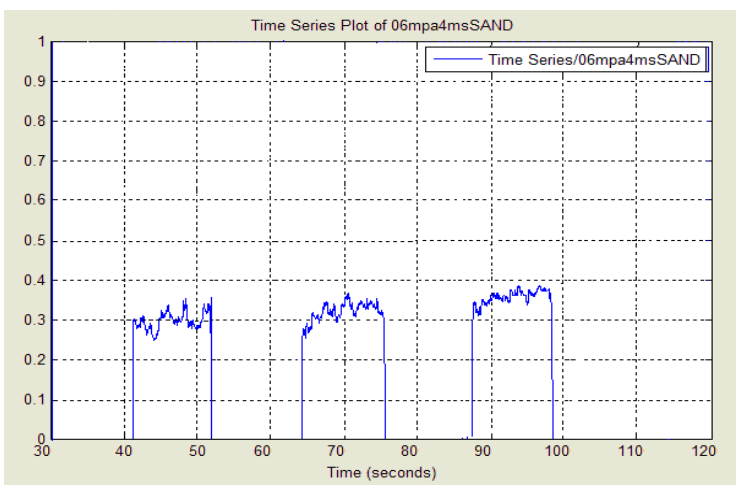

(d)

Figure $4 \mathrm{CoF}$ at $4 \mathrm{~m} / \mathrm{s}$ and $0.6 \mathrm{MPa}$ (a) no grit, (b) 50-180 $\mu \mathrm{m}$, (c) 180 $355 \mu \mathrm{m}$ and (d) $355-500 \mu \mathrm{m}$ particles present

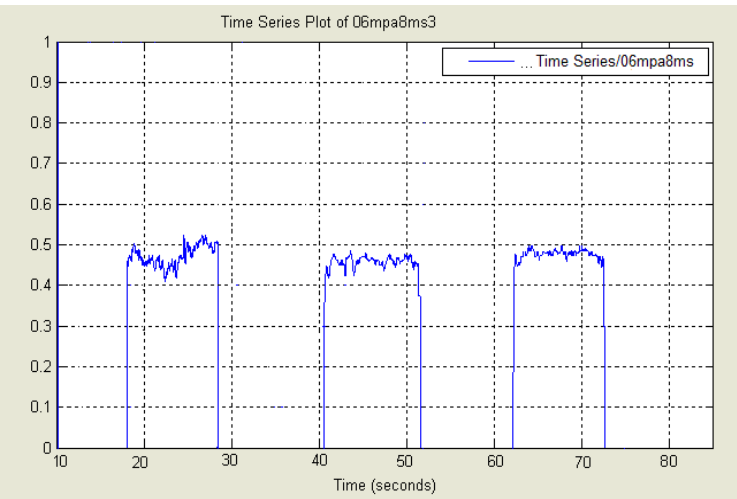

(a)

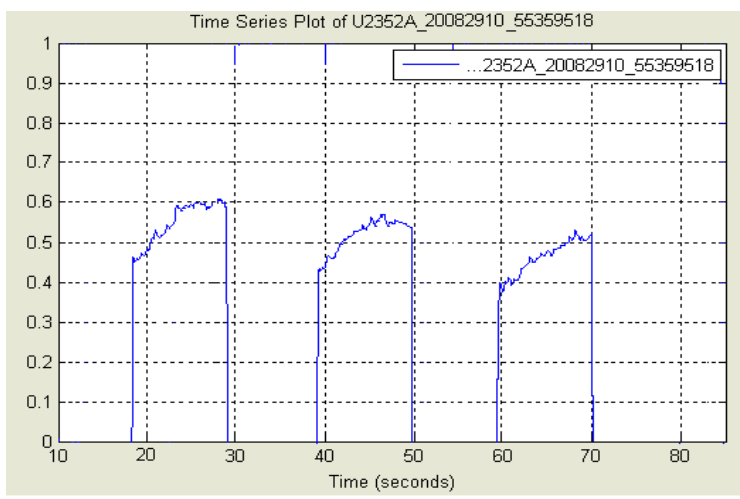

(b)

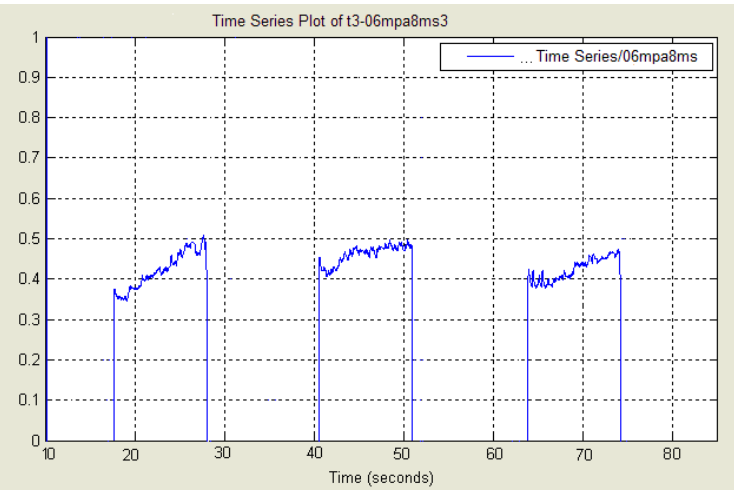

(c)

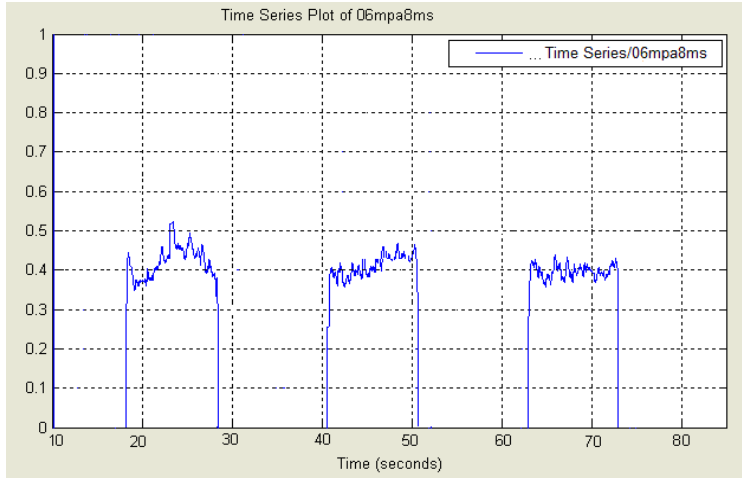

(d)

Figure 5 PPF oil viscosities were measured in a temperature range of 25 ${ }^{\circ} \mathrm{C}$ to $50{ }^{\circ} \mathrm{C}$ 
It can be seen from these figures that at low and medium speeds, the larger particle size groups tend to lower the $\mathrm{CoF}$ values. The presence of hard particles is assumed to reduce the effective contact area as they themselves become the main contact plateau when they enter the sliding contact as schematically illustrated in Figure 6. The abrupt changes of $\mathrm{CoF}$ at the beginning of braking are related to formation and growth of the contact plateaus. The $\mathrm{CoF}$ values change as these contact plateaus that form the effective contact area change. Increase in effective contact area results in a higher friction force and this also depends on the compositions of the brake pad and the sliding conditions $[18,19]$.
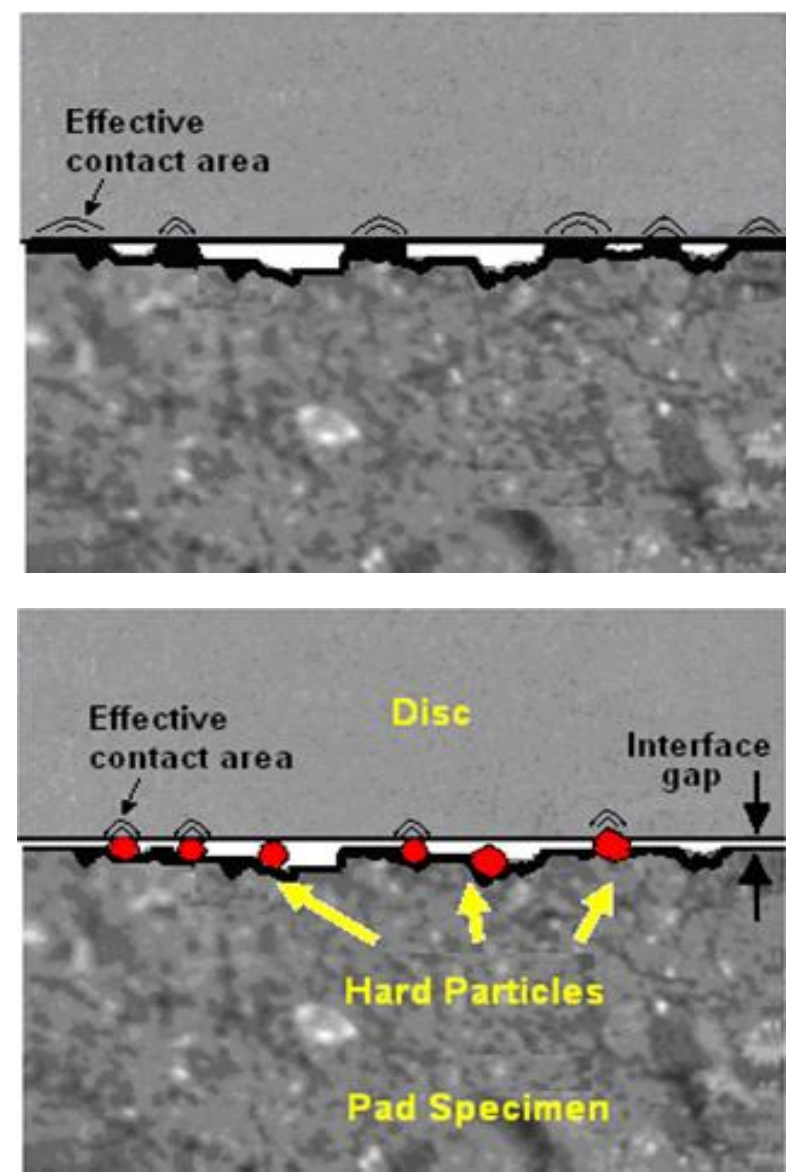

Figure 6 Schematic illustration of how presence of hard particles changes the effective contact areas at

Presence of the external grit particles at the brake interface also results in more generation of wear debris and growth of the compacted wear debris areas. However, this is influenced by the disc sliding speed, brake pressure applied, size and shape of the grit particles. Smaller particles most likely pass through the pad cavities, sometimes accumulate in the cavities increasing the effective contact area before leaving the brake gap. However, larger particles might increase the brake gap especially if they are trapped between the contact of hard material (metal fiber on the pad surface) and metal (grey cast iron disc). Also, presence of highly angular grit particles would result in a generation of fine wear debris.

Drag test results at higher disc sliding speeds are shown in Figures 7 and 8. The $\mathrm{CoF}$ values were higher compared to those obtained at low and medium speeds. However, the CoF values were reduced only for $355-500 \mu \mathrm{m}$ particles while the $\mathrm{CoF}$ values for $180-355 \mu \mathrm{m}$ and $50-180 \mu \mathrm{m}$ were increased. The difference in particle grit size has started to significantly affect the CoF values at higher sliding speeds. The increase in $\mathrm{CoF}$ values for the smaller particle size range is attributed to their active role in the mixing and changing of effective contact area. Some smaller particles filled the cavities on the pad specimen resulting in a rapid growth of the effective contact area contributing to the generation of secondary contact plateaus. Secondary plateaus composed of compacted wear debris were reported by Eriksson et al. [19]. Bigger particles formed primary contact plateaus themselves and did not participate in the formation of secondary contact plateaus [8].

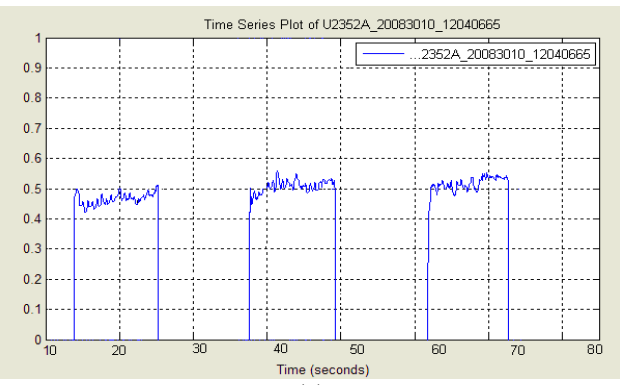

(a)

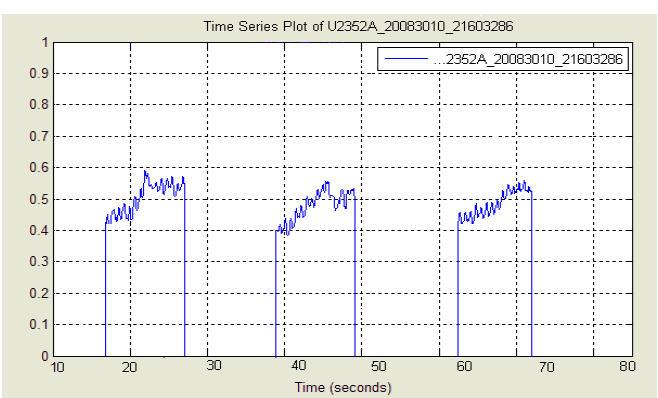

(b)

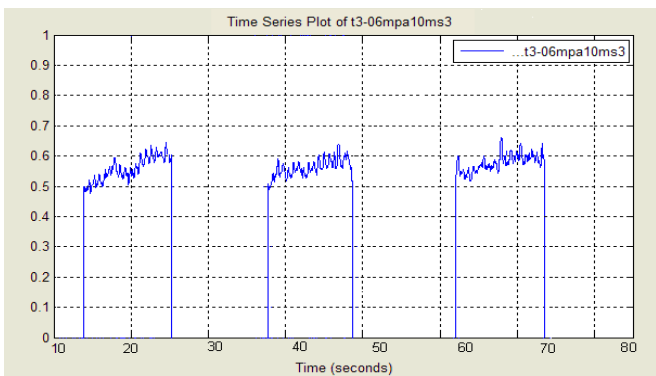

(c)

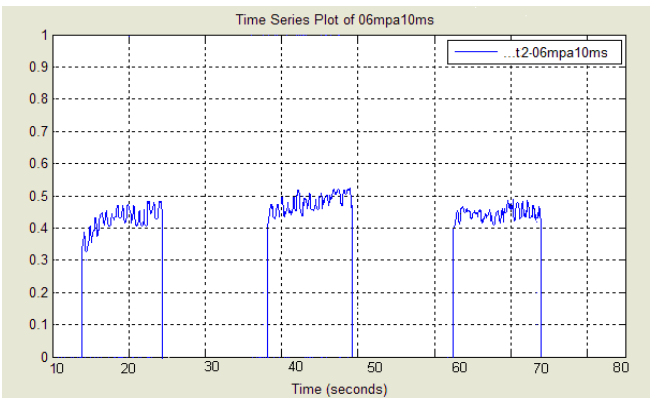

(d)

Figure $7 \mathrm{CoF}$ at $10 \mathrm{~m} / \mathrm{s}$ and $0.6 \mathrm{MPa}$ (a) no grit, (b) $50-180 \mu \mathrm{m}$ (c) $180-$ $355 \mu \mathrm{m}$ and (d) $355-500 \mu \mathrm{m}$ particles present 


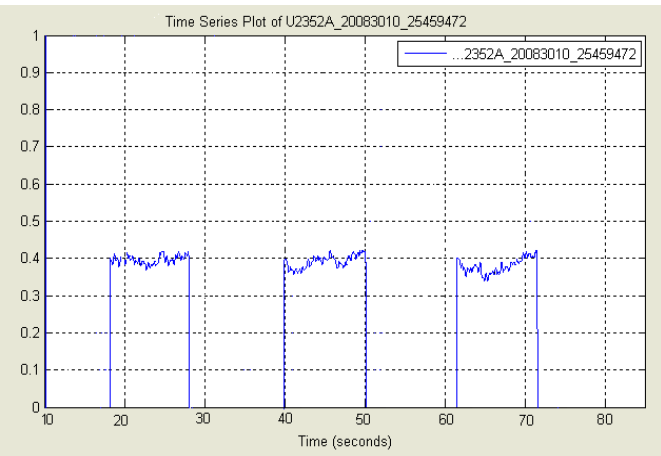

(a)

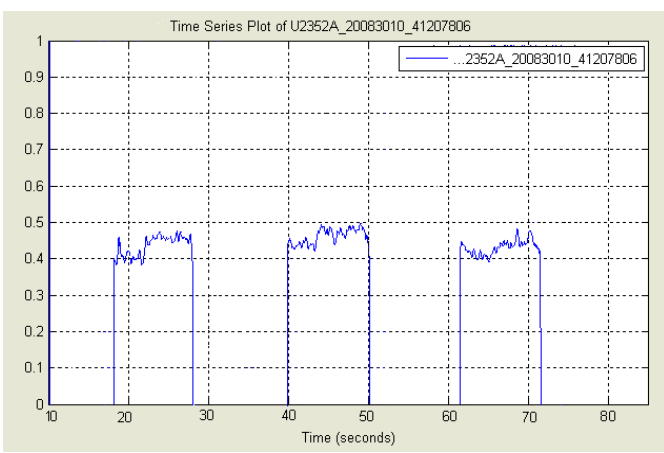

(b)

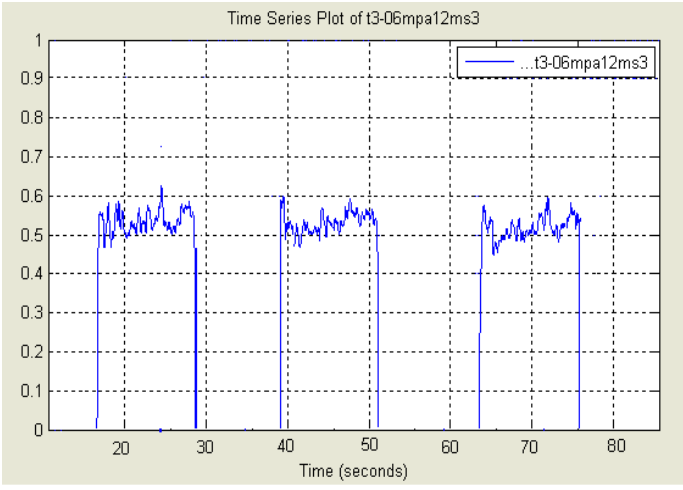

(c)

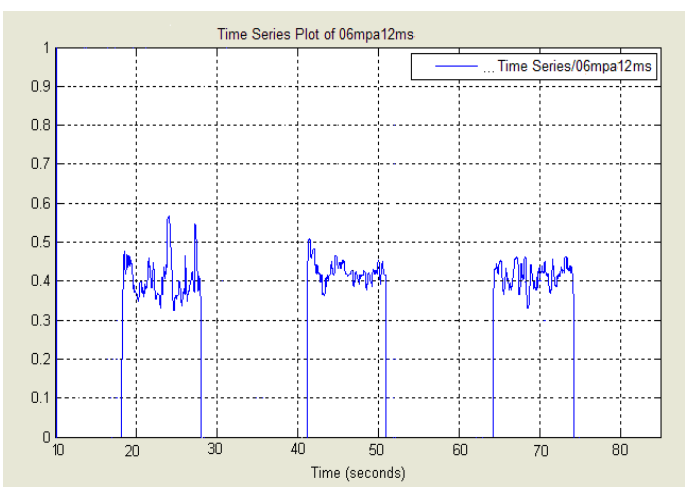

(d)

Figure $8 \mathrm{CoF}$ at $12 \mathrm{~m} / \mathrm{s}$ and $0.6 \mathrm{MPa}$ (a) no grit, (b) $50-180 \mu \mathrm{m}$, (c) 180 $355 \mu \mathrm{m}$ and (d) $355-500 \mu \mathrm{m}$ particles present

The schematic illustration of the mechanism of the influence of large and small grit particles on effective contact are changes shown in Figure 9. Also, higher sliding speeds help to accelerate the mixing process. It is possible that smaller particles roll and mix faster with other wear debris to quickly expand and stabilize the effective contact area. The CoF results shown in Figures 7 and 8 seem to support that as smaller particles result in stable $\mathrm{CoF}$ values compared to bigger particles at the same sliding speed.
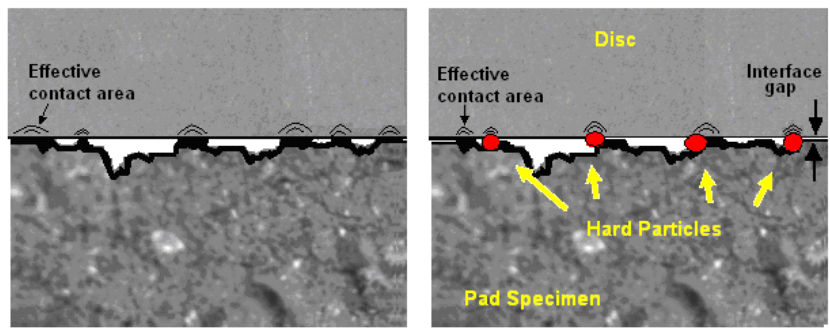

(a)
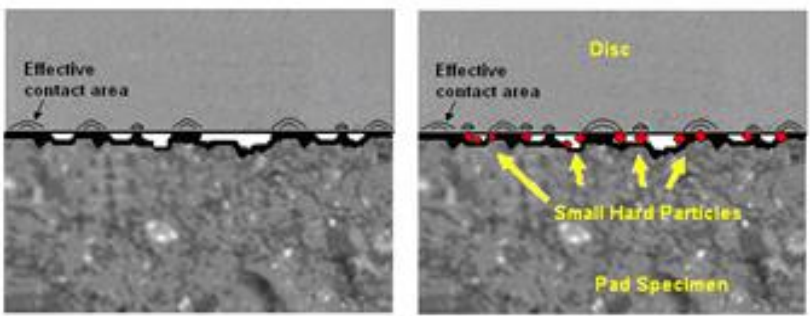

(b)

Figure 9 Grit particles and contact area: (a) effect of large grits and (b) effect of small grits.

The embedment of hard particles, as shown in Figure 10(a), resulted in the disc abrasive wear and the generation of wear particles. These grits contributed to the $2^{\text {nd }}$ body abrasion and enhanced the damage to the disc [20] as shown in Figure 10(b). Some of the wear debris generated was probably assisting the formation of friction film. The CoF values for drag tests at the contact pressure of $0.6 \mathrm{MPa}$ are shown in Table 2 .
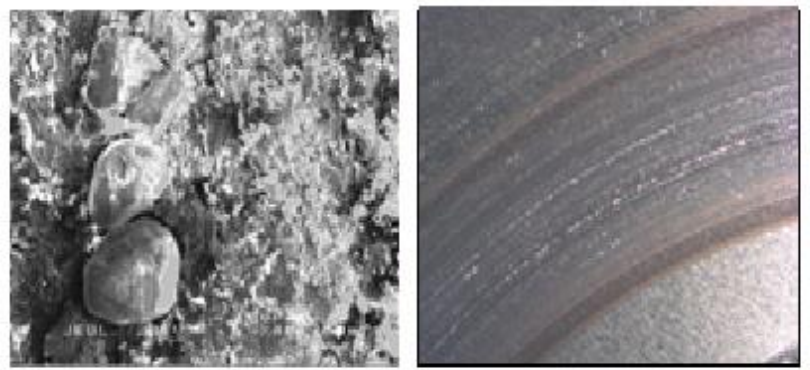

Figure 10 SEM and optical microscopy images of the embedded silica sand on brake pad and wear grooves on the disc 
Table 2 Drag test results at $0.6 \mathrm{MPa}$

\begin{tabular}{|c|c|c|c|c|c|}
\hline $\begin{array}{l}\text { Sliding } \\
\text { Speed, } \\
\mathbf{v}(\mathbf{m} / \mathbf{s})\end{array}$ & $\begin{array}{l}\text { 3x Ave. CoF, } \\
\text { (No Grit) }\end{array}$ & \multicolumn{2}{|c|}{$\begin{array}{r}\text { 3x Ave. CoF, } \\
(50-180 \mu \mathrm{m})\end{array}$} & $\begin{array}{l}\text { 3x Ave. CoF } \\
(180-355 \mu \mathrm{m})\end{array}$ & $\begin{array}{l}\text { 3x Ave. CoF, } \\
(355-500 \mu \mathrm{m})\end{array}$ \\
\hline 4 & $\begin{array}{l}0.49,0.45,0 . \\
43\end{array}$ & $\begin{array}{l}0.47, \mathrm{C} \\
0.41\end{array}$ & & $\begin{array}{l}0.38,0.31, \\
0.35\end{array}$ & $\begin{array}{l}0.33,0.31, \\
0.35\end{array}$ \\
\hline 8 & $\begin{array}{ll}0.46, & 0.46 \\
0.5 & \end{array}$ & $\begin{array}{l}0.55 \\
0.47\end{array}$ & 0.5 & $\begin{array}{l}0.41,0.48, \\
0.44\end{array}$ & $\begin{array}{ll}0.44, & 0.41 \\
0.4 & \end{array}$ \\
\hline 10 & $\begin{array}{l}0.47,0.51,0 \\
52\end{array}$ & $\begin{array}{l}0.5 \\
0.48\end{array}$ & 0.47 & $\begin{array}{l}0.55,0.56 \\
0.57\end{array}$ & $\begin{array}{l}0.42,0.47, \\
0.45\end{array}$ \\
\hline 12 & $\begin{array}{l}0.4, \quad 0.4 \\
0.39\end{array}$ & $\begin{array}{l}0.45, \\
0.44\end{array}$ & & $\begin{array}{l}0.53,0.52 \\
0.51\end{array}$ & $\begin{array}{l}0.38 \\
0.4\end{array}$ \\
\hline
\end{tabular}

\subsection{Effect of Hard Particle Grit Size on Friction Coefficient} Oscillation Amplitude

The friction oscillation amplitude results with and without the presence of hard particle, are shown in Figure 11. Without hard grits, the CoF oscillation amplitude is largest at low sliding speeds especially at the beginning of the braking operation as shown in Figure 11(a). But towards the end of braking $\mathrm{CoF}$ oscillation amplitude is larger at higher speeds. For particle size of 355-500 $\mu \mathrm{m}$, Figure 11(b), the CoF oscillation amplitudes were reduced for almost all the cases especially at the end of braking.

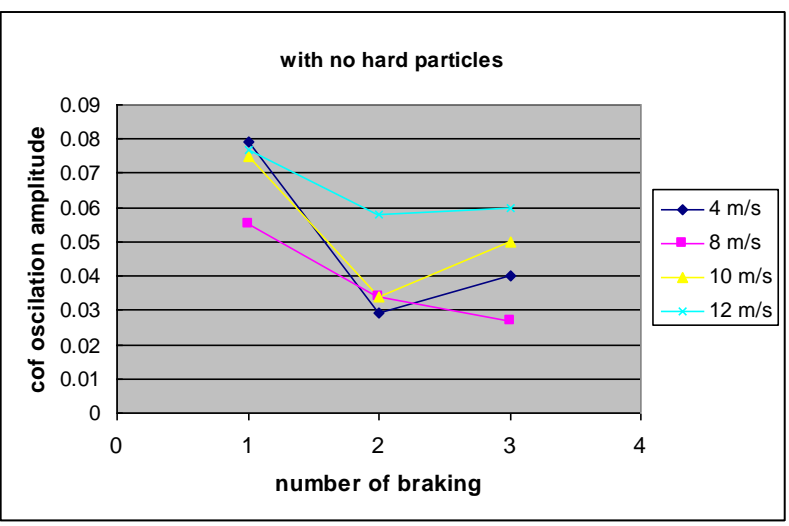

(a)

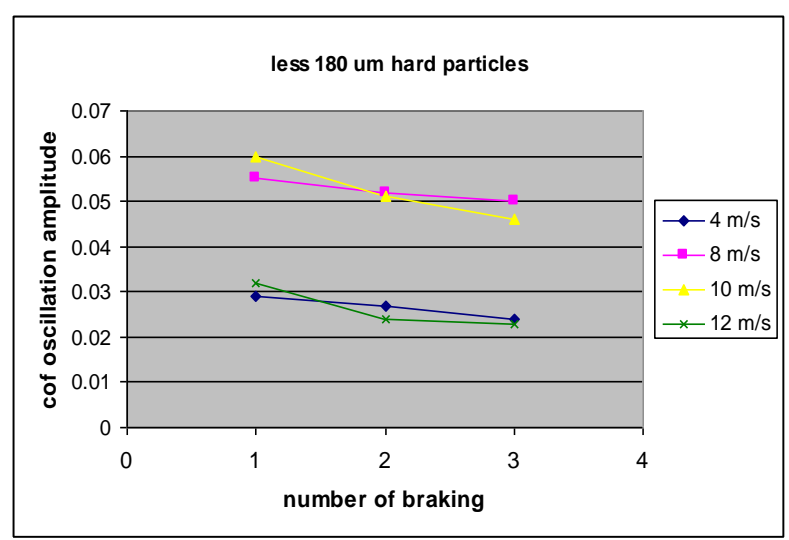

(b)

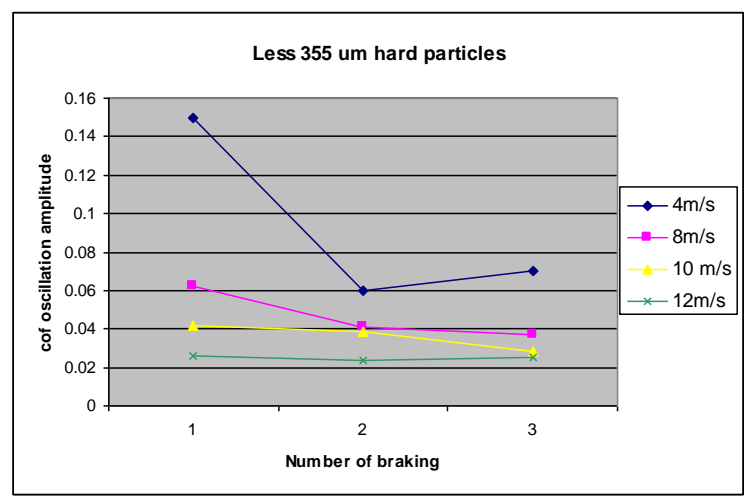

(c)

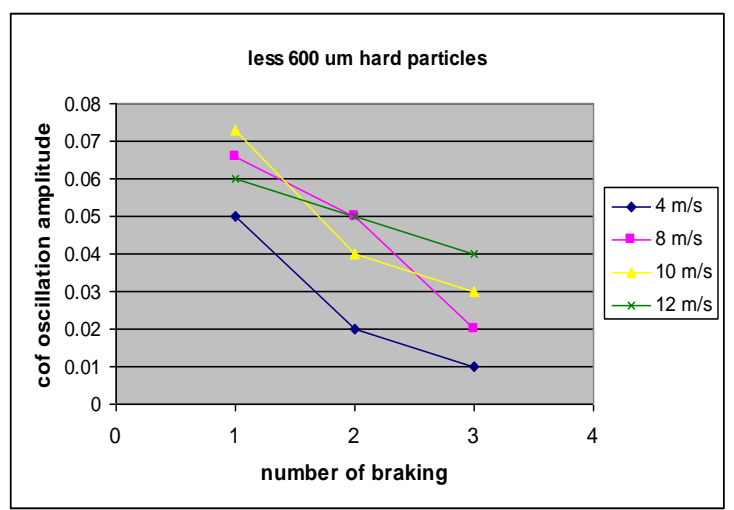

(d)

Figure 11 The CoF oscillation amplitude at four different sliding speeds with (a) without grits, (b) $50-180 \mu \mathrm{m}$, (c) $180-355 \mu \mathrm{m}$ and (d) $355-500 \mu \mathrm{m}$ particles present

More wear debris was also observed on the brake pad when grit particles were present as shown in Figure 12(b)-(d). However, smaller hard particles tend to produce larger numbers of smaller wear debris compared to larger grits. Thus the presence of grit particle has significant effect on the friction oscillation as more wear debris are generated forming frictional film on the braking interface [21].

The friction oscillation amplitude with $180-355 \mu \mathrm{m}$ particles present is largest at low sliding speed becoming gradually reduced at medium and higher speeds as shown in Figure 11(c). For smaller grits of 50-180 $\mu \mathrm{m}$, friction oscillation amplitude values were reduced for all cases especially at high sliding speed as shown in Figure 11(d). This is due to the grit particle size effect providing more stable contact at higher speeds by building up the effective contact area at sliding interface. 


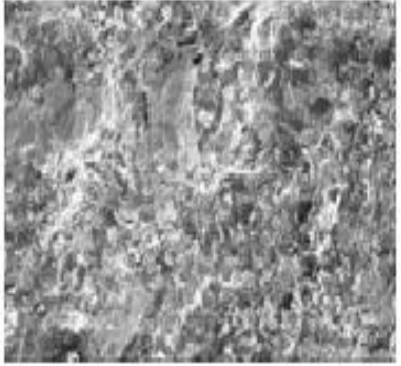

(a)

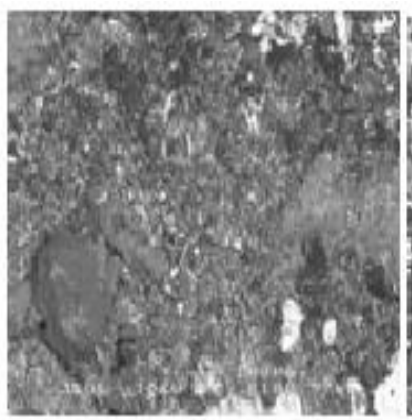

(c)

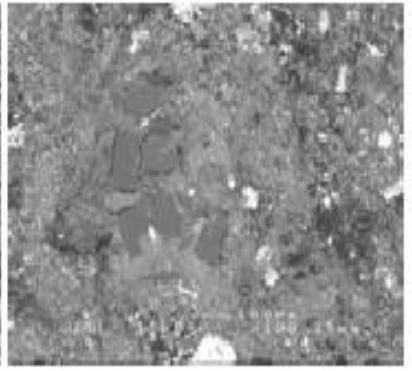

(b)

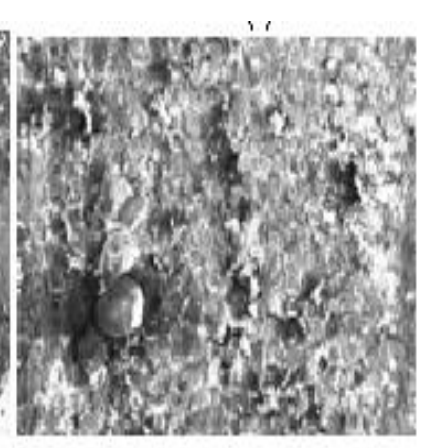

(d)

Figure 12 Wear debris of (a) without grit, (b) 50-180 $\mu \mathrm{m}$, (c) 180-355 $\mu \mathrm{m}$ and (d) 355-500 $\mu \mathrm{m}$ particles

3.3 Effect of Sliding Speed, Applied Pressure and Grit Particle on Particle Embedment

Particle embedment into the pad surfaces was analyzed to find the correlation between the particle embedment and grit size at different sliding speeds and applied pressures. The particle grit size effect on the grit embedment was investigated using SEM and optical microscopes. Few reports on grit embedment are reported [22, 23] however, little has been published on the embedment of grit particle into the brake pads. In material embedment and abrasion, factors such as particle shape, size and hardness affect the level of grit embedment.

The percentage of particle embedment of silica sand of 180$355 \mu \mathrm{m}$ as a function of speed and applied pressure is shown in Table 3. Four sliding speeds of $4 \mathrm{~m} / \mathrm{s}, 8 \mathrm{~m} / \mathrm{s}, 10 \mathrm{~m} / \mathrm{s}$ and $12 \mathrm{~m} / \mathrm{s}$ at constant pressures of $0.6 \mathrm{MPa}, 0.8 \mathrm{MPa}$ for drag mode and 1.0 $\mathrm{MPa}$ for stop mode were used. At low pressures and speeds, the percentage of embedded particles is higher than at low pressure but higher speeds. At the contact pressure of $0.8 \mathrm{MPa}$, the same pattern was observed i.e. higher percentage of grit embedment at low and medium speeds than at higher speeds. The particle embedment at contact pressure of 1.0 MPa shows different pattern with low speed tends to have lowest percentage of grit embedment compared to higher speeds.

Table 3 Percentage embedment as a function of speed and pressure for silica sand of size $180-355 \mu \mathrm{m}$

\begin{tabular}{|c|c|c|c||}
\hline $\begin{array}{c}\text { Sliding Speed } \\
\text { (m/s) }\end{array}$ & $\begin{array}{c}\text { Embedment } \\
\text { (5. Area) } \\
\text { at } 0.6 \mathrm{MPa}\end{array}$ & $\begin{array}{c}\text { Embedment } \\
\text { (5 Area) } \\
\text { at } 0.8 \mathrm{MPa}\end{array}$ & $\begin{array}{c}\text { Embedment } \\
\text { (5 Ares) } \\
\text { at } 1.0 \mathrm{MPa}\end{array}$ \\
\hline 4 & $2.0 \%$ & $1.5 \%$ & $0.5 \%$ \\
\hline 8 & $1.5 \%$ & $2.0 \%$ & $1.5 \%$ \\
\hline 10 & $1.0 \%$ & $1.0 \%$ & $1.5 \%$ \\
\hline 12 & $1.0 \%$ & $1.0 \%$ & $1.0 \%$ \\
\hline
\end{tabular}

From the results obtained, it can be seen that speed and load significantly influence the level of grit embedment. At lower speed, the percentage of grit embedment is higher due to larger number of compacted wear debris assisting the embedment. However, as the speed increases, the percentage of grit embedment is slightly reduced as more wear debris was ejected and less compacted wear debris was present.

In an attempt to better understand the mechanisms of grit embedment, worn surfaces of the brake pads were examined in SEM. The size of the embedded particles was measured to check whether grit fragmentation has occurred and how deep was the embedment. Grit particles that were partially or half embedded below the surface of the brake pad are shown in Figure 13.

However, no fully embedment grits was found at $0.6 \mathrm{MPa}$ and $0.8 \mathrm{MPa}$ for all the speeds. Most of the embedded grits were scattered in the size range of 180 to $350 \mu \mathrm{m}$. No fragmentation of grits occurred as particle below the original size range could not be found. This is due to low applied pressure.

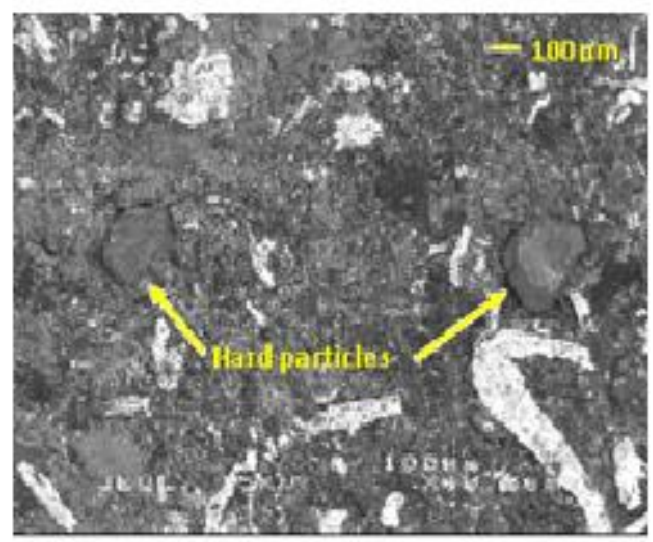

Figure 13 Two half embedded grit particles of the size between 180-355 $\mu \mathrm{m}$ at $0.6 \mathrm{MPa}$.

At the contact pressure of 1.0 MPa, few fully embedded grits were observed and most of the grit particles were embedded next to the compacted wear debris. The example of fully embedded grit particle covered by compacted wear debris at $1.0 \mathrm{MPa}$ is shown in Figure 14. Most of the embedded grit particles observed was in the size range of 50 to $350 \mu \mathrm{m}$. A few particles smaller, than the original particle grit size range, were found suggesting some particle fragmentation has occurred. The fragmented particles were more angular, i.e. they were more easily embedded into the pad surface. These results show that high applied pressure may results in particle fragmentation and full embedment.

When investigating the particle grit size effect on the particle embedment, slight increase in percentage of particle embedment 
was observed when particles in the range of $355-500 \mu \mathrm{m}$ were used. Larger particles tend to cover maximum of $3 \%$ of the pad area compared to $2 \%$ and $0.8 \%$ with smaller particles. No fully embedded particle was found during SEM examination for larger particles but partially embedded grits were observed in all the size ranges. Few smaller particles were fully embedded into the cavities on the pad and many more were embedded next to the compacted wear debris. Difference in grit embedment is probably due their different angularity. Smaller particles are more angular but the angularity effect on the grit embedment would need to be thoroughly investigated.

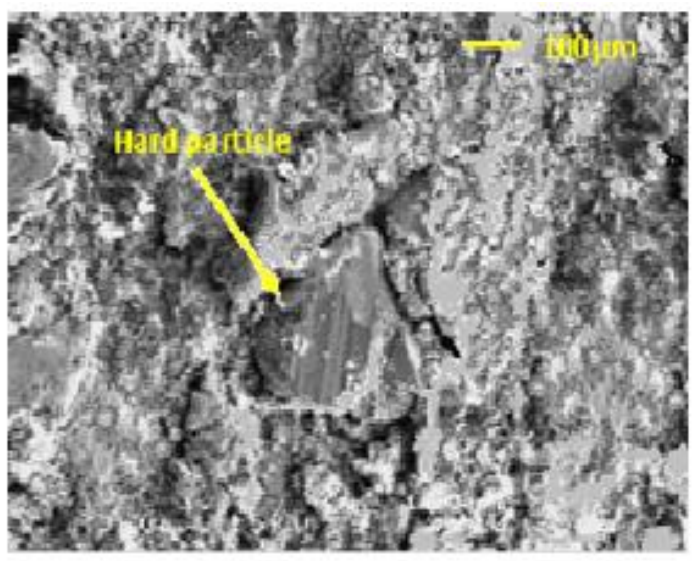

Figure 14 Fully embedded grit particle next to compacted wear debris at contact pressure of $1.0 \mathrm{MPa}$

\subsection{CONCLUSION}

The particle grit size effect on frictional performance of disc brake was investigated using a specially developed brake test rig. Three different size range of silica sand grits of 50-180 $\mu \mathrm{m}, 180$ $355 \mu \mathrm{m}$ and 355-500 $\mu \mathrm{m}$ were used during the test. The changes of friction coefficient, the fluctuation of frictional force and the particle embedment were investigated during the drag mode braking application. Experimental results showed that:

- The presence of hard particles has significant effect on reducing $\mathrm{CoF}$ values especially at lower sliding speeds.

- The values of $\mathrm{CoF}$ increase with smaller hard particle grit size due to their active role in building up the effective contact areas/plateaus.

- The particle size effect influences the sensitivity of the CoF oscillation amplitude at higher speeds by providing more stable contact with smaller particles actively involved in building up and reducing the rate of changes of the effective contact area.

- GE was greatly dependent on presence of compacted wear debris as most grits were found embedded into compacted wear debris.

\section{Acknowledgement}

The authors would like to express their thanks to staff of School of Mechanical and Chemical Engineering, University of Western Australia, for their assistance in carrying out this research work. The authors also acknowledge the Government of Malaysia and Universiti Teknologi Malaysia for their financial assistance.

\section{References}

[1] Eriksson, M., Bergman, F., Jacobson, S. 2002. On the Nature of Tribological Contact in Automotive Brakes. Wear. 252(1-2). 26-36.

[2] Polak, A., Grzybek, J. 2005. The Method of Friction Mechanism Investigation in Automotive Disc Brake in the Presence of Hard Particle, Conference. Triboscience and Tribotechnology-Superior Friction and Wear Control in Engine and Transmission. 231-239.

[3] Handa, Y., Kato, T. 1996. Effects of Cu Powder, $\mathrm{BaSO}_{4}$ and Cashew Dust on the Wear and Friction Characteristics of Automotive Brake Pads. Tribology Transactions. 39(2): 346-353.

[4] Jang, H., Kim, S. J. 2000. The Effects of Antimony Trisulfide (Sb2S3) and Zirconium Silicate $(\mathrm{ZrSiO} 4)$ in the automotive Brake Friction Material on Friction Characteristics. Wear. 239(2): 229-236.

[5] Ostermeyer, G. P. and Muller, M. 2006. Dynamic Interaction of Friction and Surface Topography in Brake Systems. Tribology International. 39(5): 370-380.

[6] Stachowiak, G. W., Batchelor, A. W. 1994. Engineering Tribology. 2nd ed. Butterworth Heinemann

[7] Axen, N., Jacobson, S., Hogmark, S. 1994. Influence of Hardness of the Counterbody in Three-Body Abrasive Wear-An Overlooked Hardness Effect. Tribology International. 27(4): 233-241.

[8] Cho, K. H., Jang, H., Hong, Y. S., Kim, S. J., Basch, R. H., Fash, J. W. 2008. The Size Effect of Zircon Particles on the Friction Characteristics of Brake Lining Materials. Wear. 264(3-4): 291-297.

[9] Trezona, R. I., Allsopp, D. N., Hutchings, I. M. 1999. Transitions between Two-body and Three-body Abrasive Wear: Influence of Test Conditions in the Microscale Abrasive Wear Test. Wear. 225-229(Part 1) 205-214

[10] Syahrullail, S., Nakanishi, K., Kamitani, S. 2005. Investigation of the Effects of Frictional Constraint with Application of Palm Olein Oil Lubricant and Paraffin Mineral Oil Lubricant on Plastic Deformation by Plane Strain Extrusion. Journal of Japanese Society of Tribologists. 50(12): 877-885

[11] Syahrullail, S., Kamitani, S., Nakanishi, K. 2012. Experimental Evaluation of Refined, Bleached, and Deodorized Palm Olein and Palm Stearin in Cold Extrusion of Aluminum A1050. Tribology Transactions, 55(2): 199-209.

[12] Cho, M. H., Cho, K. H., Kim, S. J., Kim, D. H., Jang, H. 2005. The Role of Transfer Layers on Friction Characteristics in the Sliding Interface Between Friction Materials Against Gray Iron Brake Discs. Tribology Letters. 20(2).

[13] Fischer, T. E., Singer, I. L., Pollock, H. M. 1992. Fundamentals of Friction - Macroscopic and Microscopic Processes. Dordrecht: Kluwer Academic Publishers. 299

[14] Scieszka, S. F. 1980. Tribological Phenomena in Steel-composite Brake Material Friction Pairs. Wear. 64(2): 367-378.

[15] Filip, P., Weiss, Z., Rafaja, D. 2002. On Friction Layer Formation in Polymer Matrix Composite Materials for Brake Applications. Wear. 252(3-4): 189-198

[16] Rhee, S. K., Jacko, M. G., Tsang, P. H. 1990. The Role of Friction Film in Friction, Wear, and Noise of Automotive Brakes. SAE Technical Paper No. 900004 29-36.

[17] Osterle, W., Griepentrog, M., Gross, T., Urban, I. 2001. Chemical and Microstructural Changes Induced by Friction and Wear of Brakes. Wear. 251(1-12): 1469-1476.

[18] Osterle, W., Urban, I. 2004. Friction Layers and Friction Films on PMC Brake Pads. Wear. 257(1-2): 215-226.

[19] Eriksson, M., Lord, J., Jacobson, S. 2001. Wear and Contact Conditions of Brake Pads: Dynamical In Situ Studies Of Pad On Glass. Wear. 249(3-4): 272-278.

[20] Williams, J. A., Morris, J. H., Ball, A. 1997. The Effect of Transfer Layers on the Surface Contact and Wear of Carbon-Graphite Materials. Tribology International. 30(9): 663-676.

[21] Jang, H., Lee, J. S., Fash, J. W. 2001. Compositional Effects of the Brake Friction Material on Creep Groan Phenomena. Wear. 251(1-12): 14771483

[22] Polak, A., Grzybek, J., Stolarski, B. 2005. Noise, Vibration and Harshness in Automotive Disc Brakes Related to the Presence of Hard Particles, Conference: Triboscience and Tribotechnology-Superior Friction and Wear Control in Eng. and Trans.

[23] Abdul Hamid, M. K., Samion, S., and Stachowiak, G. W. 2012. Effects of Hard Particles on Friction Coefficients and Particle Embedment in Brake System during Hard Braking, AIP Conference Proceedings. 1440 905-913. 